\title{
HEPATIC CIRRHOSIS: EFFECTS OF SODIUM CHLORIDE AD- MINISTRATION AND RESTRICTION AND OF ABDOMINAL PARACENTESIS ON ELECTROLYTE AND WATER BALANCE ${ }^{1,2}$
}

\author{
By GEORGE J. GABUZDA, JR., ${ }^{3}$ HENRY S. TRAEGER, AND CHARLES S. DAVIDSON \\ (From the Thorndike Memorial Laboratory, Second and Fourth Medical Services (Harvard), \\ Boston City Hospital, and the Department of Medicine, Harvard Medical School)
}

(Submitted for publication July 14, 1953; accepted January 13, 1954)

The formation of ascites and edema by patients with chronic liver disease can be controlled by rigid dietary sodium restriction (1-5). When sodium is administered, ascites formation re-commences while sodium excretion usually remains minimal. These facts have not yet been integrated with the factors usually considered contributory to the formation of ascites and edema, viz.: elevated portal pressure $(6,7)$, reduced serum albumin concentration and colloid osmotic pressure (8-12), increased anti-diuretic activity (13), altered membrane permeability $(4,14)$, or altered renal tubular function (15). However, whatever the pathogenetic factors operating, fluid retention is readily conditioned by the sodium content of the diet.

The observations reported here concern patients with cirrhosis of the liver with ascites and edema in whom the alterations in electrolyte and water balance attributable to abdominal paracenteses and to sodium chloride administration and restriction were studied under controlled conditions of food, water, and sodium chloride intake.

1 This investigation was sponsored by the Commission on Liver Disease, Armed Forces Epidemiological Board, and was supported in part by a grant from the Office of The Surgeon General, United States Army, Washington, D.C., and in part by grants from Lederle Laboratories Division, American Cyanamid Company, Pearl River, New York, and from Merck and Company, Rahway, New Jersey, to Harvard University.

${ }^{2}$ A preliminary report of this investigation was included in the Proceedings of the Forty-Second Annual Meeting of the American Society for Clinical Investigation, May 1, 1950 (J. Clin. Invest., 1950, 29, 814).

8 Welch Fellow in Internal Medicine of the National Research Council. This investigation was accomplished in part during the tenure of a United States Public Health Service Postdoctorate Fellowship.

\section{MATERIALS AND METHODS}

Seven patients with chronic advanced cirrhosis of the liver with edema and ascites requiring paracentesis were selected for study. The diagnosis in each case was established by history, physical examination, and laboratory tests of liver function. Six of these patients who were chronic alcoholics presented the classical findings of cirrhosis of the liver. No predisposing factor could be established in the seventh patient (H.O.). The clinical data of these patients are given in Table I.

The patients were studied on the Thorndike metabolic ward and were ambulatory. They were maintained on a constant basal diet which provided 75 grams of protein and at least 2800 calories daily. 4 This diet contained 10 $\mathrm{mEq}$. of sodium and $104 \mathrm{mEq}$. of potassium by analysis.

Five of the patients (R. K., W. C., H. O., B. K., and B. B.) were initially observed for from two to four weeks during which $103 \mathrm{mEq}$. of sodium $(6.0 \mathrm{Gm}$. sodium chloride) were added to the basal sodium restricted diet. In addition, $W$. C. was studied during a subsequent threeweek period while receiving $51.5 \mathrm{mEq}$. of added sodium. After this initial period, the supplemental sodium was stopped, and the observations continued for two to three months on the sodium restricted diet $(10 \mathrm{mEq}$. daily). Patients J. G. and C. M. were maintained on sodium restricted regimens throughout their studies.

The patients were weighed at the same time each day under constant conditions. Daily fluid intakes were recorded and maintained relatively constant throughout each study. Total daily urine outputs were measured and suitable aliquots taken for determination of sodium and potassium. Serial measurements of hematocrit and serum sodium were made; frequent determinations were done in the immediate pre- and post-paracentesis periods. The blood specimens were obtained without stasis from an antecubital vein four hours after breakfast and following a one-hour period of bed rest. Abdominal paracenteses were executed when indicated. The volume of fluid removed was measured, and its sodium content determined. Daily clinical estimates were made of the

4 Lonalac, used in these diets as a salt-poor milk substitute, was generously provided by the Mead Johnson Company, Evansville, Indiana. 
TABLE I

Clinical and laboratory findings in patients with cirrhosis of the liver

\begin{tabular}{|c|c|c|c|c|c|c|c|c|c|c|}
\hline $\begin{array}{l}\text { Patient, } \\
\text { age and } \\
\text { sex }\end{array}$ & $\begin{array}{c}\text { Liver } \\
\text { size* }\end{array}$ & $\begin{array}{c}\text { Spleen } \\
\text { size* }\end{array}$ & $\begin{array}{c}\text { Abdomi- } \\
\text { colal } \\
\text { cllateral } \\
\text { veinst }\end{array}$ & $\begin{array}{l}\text { Esophageal } \\
\text { varices } \\
x \text {-ray } \ddagger\end{array}$ & $\begin{array}{c}\text { Serum } \\
\text { albumin }\end{array}$ & $\begin{array}{c}\text { BSP } \\
\text { \% reten- } \\
\text { tion }\end{array}$ & $\begin{array}{c}\text { Duration } \\
\text { of } \\
\text { ascites }\end{array}$ & $\begin{array}{l}\text { Number } \\
\text { abdominal } \\
\text { paracen- } \\
\text { teses }\end{array}$ & $\begin{array}{l}\text { Average } \\
\text { volume } \\
\text { ascitic } \\
\text { fuidd } \\
\text { removed }\end{array}$ & $\begin{array}{l}\text { Average } \\
\text { interval } \\
\text { between } \\
\text { paracen- } \\
\text { teses }\end{array}$ \\
\hline R. K., 43 & 4 & 2 & $4+$ & $\mathbf{P}$ & $\begin{array}{c}G \text { m. } \% \\
2.1\end{array}$ & 36 & $\begin{array}{l}\text { months } \\
6\end{array}$ & 9 & $\begin{array}{l}\text { likers } \\
10.9\end{array}$ & $\begin{array}{l}\text { days } \\
21\end{array}$ \\
\hline W. C., 70 & N.P.\& & N.P. & $3+$ & $\mathbf{P}$ & 2.5 & 25 & 3 & 12 & 7.7 & 11 \\
\hline H. O., 62 & 14 & 4 & $2+$ & $\mathbf{P}$ & 2.0 & 5 & 3 & 12 & 7.7 & 9 \\
\hline B. $K_{.,}, 53$ & 14 & 7 & $2+$ & $\mathbf{P}$ & 1.5 & 27 & 8 & 18 & 11.2 & 15 \\
\hline B. B., 47 & 7 & 4 & $4+$ & A & 2.0 & 25 & 2 & 3 & 14.3 & 31 \\
\hline J. G., 46 & 4 & N.P. & $4+$ & $\mathbf{P}$ & 2.0 & 42 & 0.5 & 1 & 15.0 & - \\
\hline C. $\underset{\sigma^{\circ}}{\text { M., }} 48$ & 1 & N.P. & $1+$ & $\mathbf{P}$ & 1.4 & - & 9 & 9 & 13.5 & 30 \\
\hline
\end{tabular}

* cm. below costal margin.

to to $4+$.

\& $=$ present, $A=$ absent.

N.P. = not palpable.

amount of ascites and edema which were graded on a 0 to $4+$ scale.

In the early studies, sodium determinations of urine, serum, and ascitic fluid were done by the method of Consolazio and Dill (16), and in the more recent studies sodium and potassium concentrations were analyzed by internal standard flame photometer $(17,18)$. Fecal and sweat losses of sodium were assumed to be $10 \mathrm{mEq}$. daily (19-23).

Bromsulphalein retention was measured 45 minutes after the intravenous injection of $5 \mathbf{m g}$. of the dye per kilogram of body weight (24). Serum albumin concentration was determined by an immunological method which utilized antihuman albumin horse serum (25).

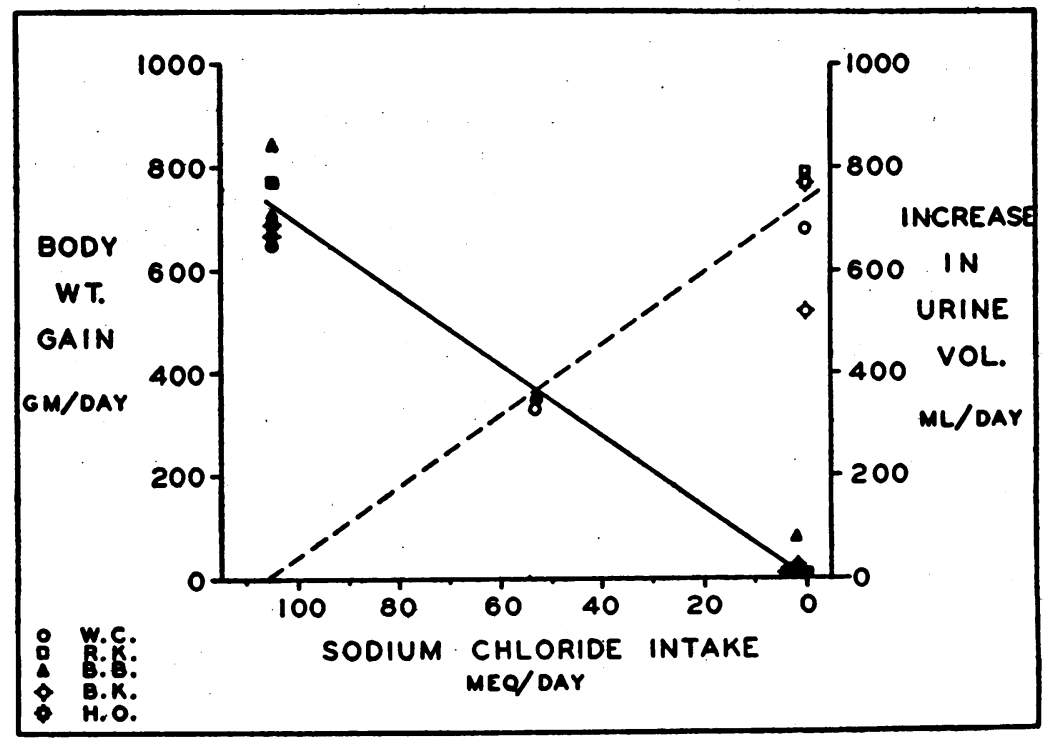

\section{FIGURE 1}

The solid diagonal line indicates the "theoretical" body weight gain expected with the isotonic retention of sodium added to the basal diet. The dashed line indicates the "theoretical" increase in urine volume expected upon withdrawing sodium from the diet. 
TABLEIII

Effect of sodium administration and restriction on body weight and urime nolume

\begin{tabular}{|c|c|c|c|c|c|c|c|c|}
\hline \multirow[b]{2}{*}{ Patient } & \multirow{2}{*}{$\begin{array}{l}\text { Days of } \\
\text { study }\end{array}$} & \multicolumn{2}{|c|}{$\begin{array}{l}\text { Sodium intake } \\
m E q . / \text { day }\end{array}$} & \multirow{2}{*}{$\begin{array}{c}\text { Fluid } \\
\text { intake } \\
\text { average }\end{array}$} & \multirow{2}{*}{$\begin{array}{c}\text { Urine } \\
\text { output } \\
\text { average }\end{array}$} & \multirow{2}{*}{$\begin{array}{l}\text { Increase } \\
\text { in urine } \\
\text { volume } \\
\text { during } \\
\text { sodium } \\
\text { restriction } \\
\text { average }\end{array}$} & \multirow{2}{*}{$\begin{array}{c}\text { Body } \\
\text { weight } \\
\text { gain } \\
\text { average* }\end{array}$} & \multirow{2}{*}{$\begin{array}{c}\text { Urine } \\
\text { sodium } \\
\text { average }\end{array}$} \\
\hline & & Diet & $\overline{\text { Added }}$ & & & & & \\
\hline R. K. & $\begin{array}{r}1-28 \\
29-43\end{array}$ & $\begin{array}{l}10 \\
10\end{array}$ & $\begin{array}{r}103 \\
0\end{array}$ & $\begin{array}{c}\text { ml./day } \\
2220 \\
2290\end{array}$ & $\begin{array}{c}m l . / \text { day } \\
1337 \\
2130\end{array}$ & $\begin{array}{c}\text { ml./day } \\
793\end{array}$ & $\begin{array}{c}\text { Gm./day } \\
783 \\
0\end{array}$ & $\begin{array}{c}m E_{q .} / \text { day } \\
1.0 \\
0.7\end{array}$ \\
\hline W. C. & $\begin{array}{r}1-14 \\
15-34 \\
35-49\end{array}$ & $\begin{array}{l}10 \\
10 \\
10\end{array}$ & $\begin{array}{c}103 \\
51.5 \\
0\end{array}$ & $\begin{array}{l}2220 \\
2210 \\
2225\end{array}$ & $\begin{array}{r}808 \\
1137 \\
1487\end{array}$ & $\begin{array}{l}329 \\
679\end{array}$ & $\begin{array}{r}649 \\
341 \\
8\end{array}$ & $\begin{array}{l}2.9 \\
1.6 \\
3.1\end{array}$ \\
\hline H. $O$. & $\begin{array}{r}1-13 \\
14-23\end{array}$ & $\begin{array}{l}10 \\
10\end{array}$ & $\begin{array}{r}103 \\
0\end{array}$ & $\begin{array}{l}2620 \\
2720\end{array}$ & $\begin{array}{l}1606 \\
2380\end{array}$ & 774 & $\begin{array}{r}673 \\
0\end{array}$ & $\begin{array}{l}1.0 \\
1.0\end{array}$ \\
\hline B. $\mathrm{K}$. & $\begin{array}{r}1-14 \\
15-35\end{array}$ & $\begin{array}{l}10 \\
10\end{array}$ & $\begin{array}{r}103 \\
0\end{array}$ & $\begin{array}{l}1380 \\
1360\end{array}$ & $\begin{array}{r}668 \\
1180\end{array}$ & .512 & $\begin{array}{r}666 \\
0\end{array}$ & $\begin{array}{l}0.6 \\
1.6\end{array}$ \\
\hline B. B. & $\begin{array}{r}1-13 \\
14-29 \\
30-44\end{array}$ & $\begin{array}{l}10 \\
10 \\
10\end{array}$ & $\begin{array}{r}103 \\
103 \\
0\end{array}$ & $\begin{array}{l}2380 \\
2030 \\
1890\end{array}$ & $\begin{array}{r}979 \\
967 \\
1197\end{array}$ & $t$ & $\begin{array}{c}691 \\
845 \\
93 \ddagger\end{array}$ & $\begin{array}{l}0.8 \\
0.6 \\
0.7\end{array}$ \\
\hline
\end{tabular}

* The expected gains in body weight with the isotonic retention of the quantities of sodium added to the basal diet are $736 \mathrm{Gm}$. and $368 \mathrm{Gm}$., respectively.

+ Calculation not made because of marked fluctuations in fluid intake.

\# A total body weight gain of 295 grams during this period of study occurred during the five days immediately following paracentesis on day 30 .

Blood hematocrit was determined by the method of Wintrobe (26).

These studies were done during the winter and spring months so that variations in skin losses of water and sodium were minimal.

The patients studied presented no clinical or laboratory evidence of cardiac or renal disease, nor was any patient's course complicated by vomiting, diarrhea, or gastrointestinal bleeding, except in patient B. B. as indicated below.

\section{RESULTS}

\section{Sodium Chloride Administration}

\section{A. Sodium and water balances}

The five patients (R. K., B. B., B. K., H. O., and W. C.) who were maintained for two to four weeks on the diet providing $10 \mathrm{mEq}$. of sodium daily to which $103 \mathrm{mEq}$. of sodium was added as sodium chloride, accumulated ascites and edema at a rate (as measured by body weight gain) averaging 720 grams per day for all studies. The weight gains for each of these patients during periods of sodium ingestion are shown in Table II. This is similar to the weight gain expected if the $103 \mathrm{mEq}$. of added sodium were retained isotonically (140 $\mathrm{mEq}$. per L.), namely 736 grams per day (Figure 1). A similar relationship was observed in W. C.
(Table II) while he ingested $51.5 \mathrm{mEq}$. of sodium daily in addition to the basal diet.

\section{B. Physiologic alterations attributable to para- centesis}

These observations were made while the patients continued to ingest relatively constant fluid intakes, and diets constant in calories, nitrogen and sodium content to which $103 \mathrm{mEq}$. of sodium chloride were added daily, except in the case of C. M. who was maintained on a sodium restricted regimen.

Body weight: During the first several days following paracentesis the body weights of $\mathrm{R}$. K., B. B., and B. K. (Figures 2, 3, and Table III) increased rapidly. The amount of weight increase exceeded the weight gain expected if the ingested sodium was retained isotonically with water. C. M. also displayed a rapid weight gain while on a sodium restricted regimen. This alteration in body weight following paracentesis was not observed in H. O. and W. C. (Table III).

Ascites and edema: Following paracentesis, ascites rapidly reaccumulated, and edema decreased. Some patients who had moderate to marked pitting edema of the lower extremities were free of edema or displayed marked decreases in the amount of 


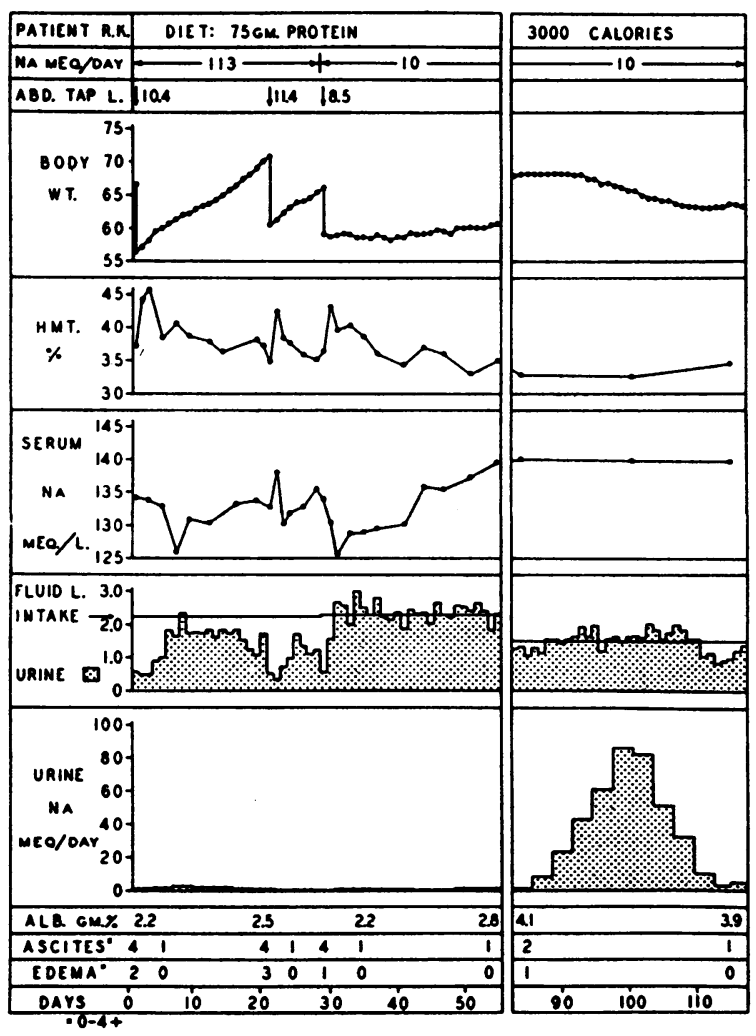

Figure 2

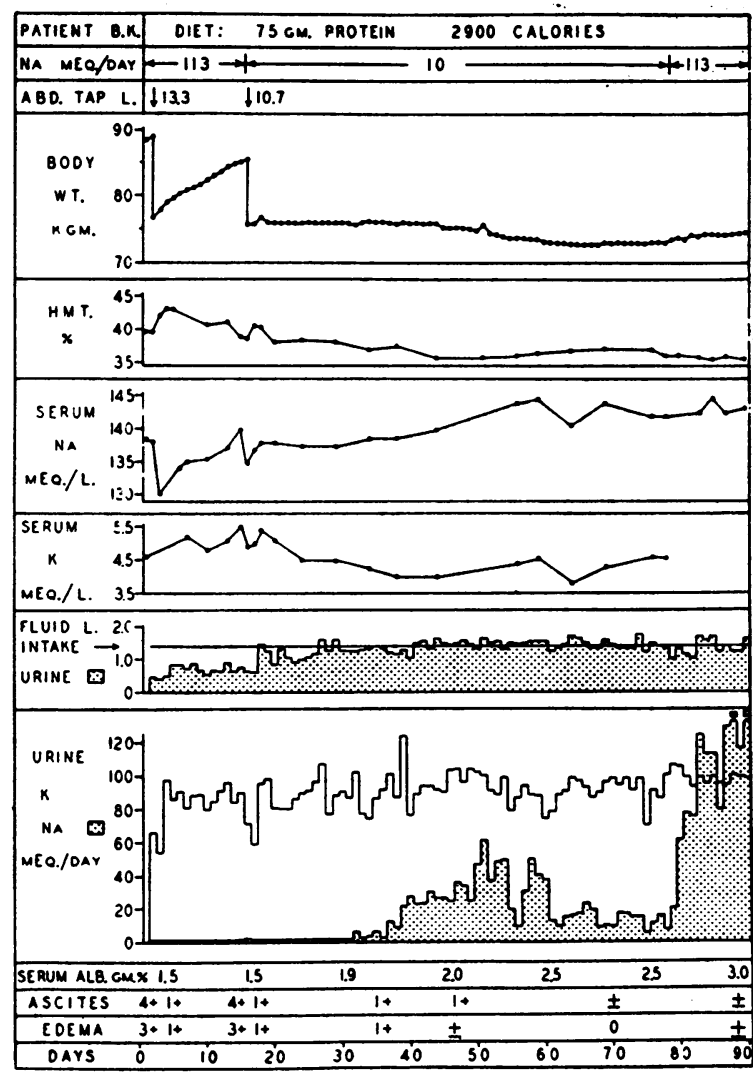

Figure 3

TABLE III

Effect of paracentesis on body weight and urine volume

\begin{tabular}{|c|c|c|c|c|c|c|}
\hline Patient & $\begin{array}{c}\text { Days of } \\
\text { study }\end{array}$ & $\begin{array}{c}\text { Sodium } \\
\text { intake }\end{array}$ & $\begin{array}{c}\text { Fluid } \\
\text { intake } \\
\text { average }\end{array}$ & $\begin{array}{c}\text { Urine } \\
\text { output } \\
\text { average }\end{array}$ & $\begin{array}{c}\text { Body } \\
\text { weight } \\
\text { gain } \\
\text { average }\end{array}$ & $\begin{array}{c}\text { Urine } \\
\text { sodium } \\
\text { average }\end{array}$ \\
\hline R. K. & $\begin{array}{c}1^{*}-3 \\
4-20 \\
21^{*}-23 \\
24-28\end{array}$ & $\begin{array}{c}m E q . / \text { day } \\
113 \\
113 \\
113 \\
113\end{array}$ & $\begin{array}{c}\text { ml./day } \\
1740 \\
2330 \\
2100 \\
2130\end{array}$ & $\begin{array}{c}\text { ml./day } \\
527 \\
1623 \\
520 \\
1140\end{array}$ & $\begin{array}{c}\text { Gm./day } \\
1061 \\
682 \\
1023 \\
727\end{array}$ & $\begin{array}{c}m E q . / \text { day } \\
0.9 \\
1.2 \\
0.3 \\
0.8\end{array}$ \\
\hline W. C. & $\begin{array}{l}1^{*}-3 \\
4-14\end{array}$ & $\begin{array}{l}113 \\
113\end{array}$ & $\begin{array}{l}2160 \\
2240\end{array}$ & $\begin{array}{l}863 \\
792\end{array}$ & $\begin{array}{l}750 \\
610\end{array}$ & $\begin{array}{l}9.9 \\
1.0\end{array}$ \\
\hline H. 0. & $\begin{array}{l}1^{*}-3 \\
4-13\end{array}$ & $\begin{array}{l}113 \\
113\end{array}$ & $\begin{array}{l}2550 \\
2640\end{array}$ & $\begin{array}{l}1540 \\
1636\end{array}$ & $\begin{array}{l}633 \\
690\end{array}$ & $\begin{array}{l}0.8 \\
1.0\end{array}$ \\
\hline B. $\mathbf{K}$. & $\begin{array}{l}1 *-3 \\
4-14\end{array}$ & $\begin{array}{l}113 \\
113\end{array}$ & $\begin{array}{l}1380 \\
1380\end{array}$ & $\begin{array}{l}467 \\
723\end{array}$ & $\begin{array}{r}1080 \\
578\end{array}$ & $\begin{array}{l}0.5 \\
0.6\end{array}$ \\
\hline B. B. & $\begin{array}{l}14^{*}-16 \\
17-29\end{array}$ & $\begin{array}{l}113 \\
113\end{array}$ & $\begin{array}{l}2000 \\
2030\end{array}$ & $\begin{array}{r}745 \\
1000\end{array}$ & $\begin{array}{r}1098 \\
787\end{array}$ & $\begin{array}{l}0.5 \\
0.6\end{array}$ \\
\hline C. M. & $\begin{array}{l}1 *-3 \\
4-9\end{array}$ & $\begin{array}{l}10 \\
10\end{array}$ & $\begin{array}{l}3600 \\
3700\end{array}$ & $\begin{array}{r}875 \\
2165\end{array}$ & $\begin{array}{r}900 \\
0\end{array}$ & 二 \\
\hline
\end{tabular}

* Day on which abdominal paracentesis was done. 


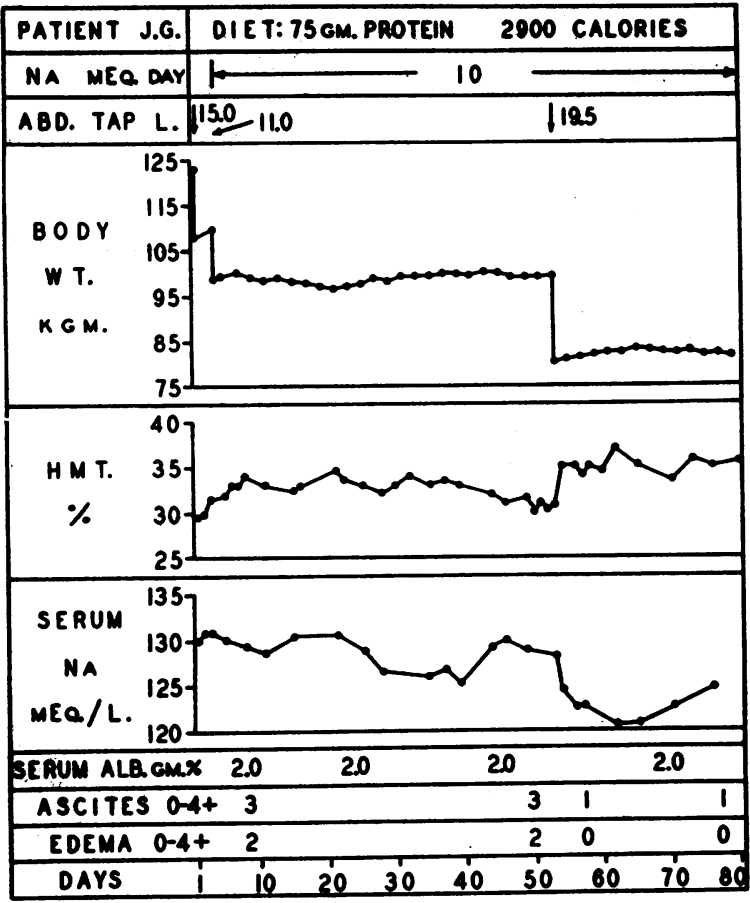

Figure 4 edema within several days after abdominal paracentesis (Figures 2, 3, 4). During this time ascites expanded out of proportion to gain in body weight suggesting that the edema fluid was shifting to the peritoneal cavity. Abdominal paracentesis became necessary again after only a few days in some of the patients. In these cases the amount of ascitic fluid obtained on repeat tap was much greater than could be accounted for by gain in body weight.

Urine volumes: Reduction in urine volume occurred on those days on which body weights increased rapidly immediately following paracentesis. Urinary sodium excretion which was minimal remained unchanged during these periods. These data are presented in Table III.

Hematocrit: Hematocrits frequently increased following paracenteses (Table IV). Progressive increases in hematocrit were noted in those patients in whom repeated paracenteses were necessary at intervals of several days (R. K., J. G., Table IV). These rapidly occurring alterations in hematocrit observed over short periods of time indicate (as-

TABLE IV

Alterations in hematocrit following paracentesis

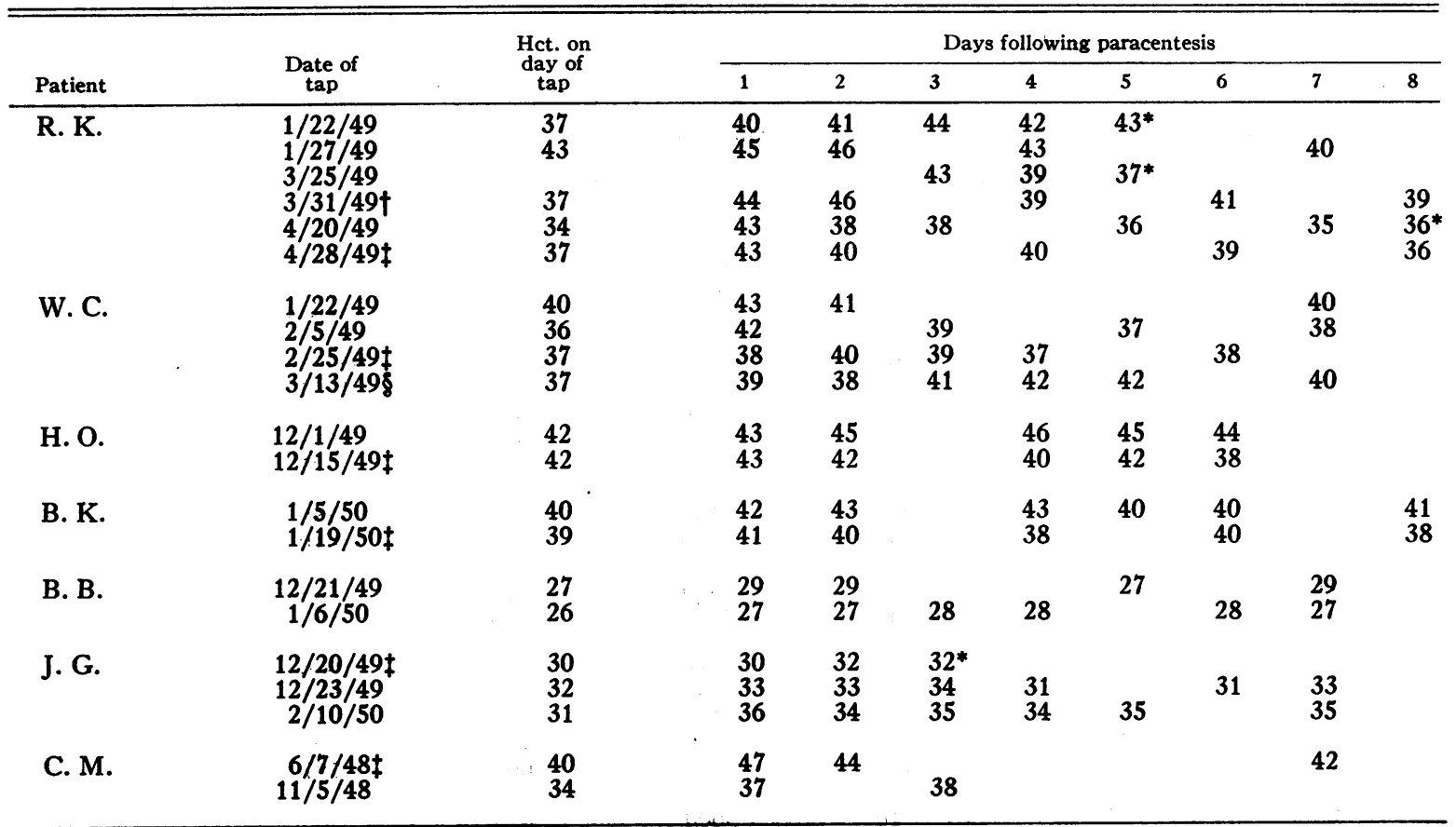

* A paracentesis necessary on this day because of a shift in edema fluid.

$\uparrow$ Hematocrit data following this date are included in Figure 2.

\$ Sodium restricted diet instituted.

$\$$ Spontaneous rupture of umbilical hernia with drainage of ascitic fluid for three days. 
TABLE V

Sodium balance data during periods of sodium administration and sodium restriction

\begin{tabular}{|c|c|c|c|c|c|c|c|c|c|c|c|c|c|c|c|}
\hline \multirow[b]{3}{*}{ Patient } & \multirow{3}{*}{$\begin{array}{c}\text { Days } \\
\text { of } \\
\text { study }\end{array}$} & \multirow{3}{*}{$\begin{array}{l}\text { Day } \\
\text { of } \\
\text { tap }\end{array}$} & \multirow{3}{*}{$\begin{array}{l}\text { Volume } \\
\text { ascitic } \\
\text { fluid }\end{array}$} & \multirow{3}{*}{$\begin{array}{c}\mathrm{Na} \\
\text { ascitic } \\
\text { fluid }\end{array}$} & \multirow[b]{3}{*}{$\begin{array}{c}\mathrm{Na} \\
\text { serum }\end{array}$} & \multirow{3}{*}{$\begin{array}{c}\text { Total } \\
\text { ascitic } \\
\mathbf{N a}\end{array}$} & \multirow{3}{*}{$\begin{array}{c}\text { Days } \\
\text { of } \\
\text { study }\end{array}$} & \multicolumn{8}{|c|}{ Sodium, $m E q . / d a y$} \\
\hline & & & & & & & & \multicolumn{4}{|c|}{ Output } & \multicolumn{3}{|c|}{ Intake } & \multirow[b]{2}{*}{ Balance } \\
\hline & & & & & & & & Ascitic & $\begin{array}{l}\text { Extra- } \\
\text { renal }\end{array}$ & Urine & Total & Diet & Added & Total & \\
\hline \multirow[t]{2}{*}{ R. K. } & $1-28$ & $\begin{array}{r}1 \\
21 \\
29\end{array}$ & $\begin{array}{r}m l . \\
10,350 \\
11,375 \\
8,500\end{array}$ & $\begin{array}{c}m E q . / L . \\
134 \\
137 \\
132\end{array}$ & $\begin{array}{c}m E q . / L . \\
134 \\
138 \\
132\end{array}$ & $m E q$ & 28 & 96 & 10 & 1 & 107 & 10 & 103 & 113 & \\
\hline & $29-43$ & & & & & & 15 & 0 & 10 & 1 & 11 & 10 & 0 & 10 & -1 \\
\hline \multirow[t]{3}{*}{ W. C. } & $1-14$ & $\begin{array}{r}1 \\
15\end{array}$ & $\begin{array}{l}8,900 \\
8,575\end{array}$ & $\begin{array}{l}146 \\
137\end{array}$ & $\begin{array}{l}143 \\
138\end{array}$ & 1,175 & 14 & 84 & 10 & 3 & 97 & 10 & 103 & 113 & +16 \\
\hline & $15-34$ & 35 & 8,600 & 139 & 141 & 1,195 & 20 & 60 & 10 & 2 & 72 & 10 & 52 & 62 & -10 \\
\hline & $35-49$ & & & & & & 15 & 0 & 10 & 3 & 13 & 10 & 0 & 10 & -3 \\
\hline \multirow[t]{2}{*}{ H. 0.} & $1-13$ & $\begin{array}{r}1 \\
14\end{array}$ & $\begin{array}{l}9,700 \\
8,350\end{array}$ & $\begin{array}{l}133 \\
137\end{array}$ & $\begin{array}{l}132 \\
138\end{array}$ & 1,144 & 13 & 88 & 10 & 1 & 99 & 10 & 103 & 113 & +14 \\
\hline & $14-23$ & & & & & & 12 & 0 & 10 & 1 & 11 & 10 & 0 & 10 & - \\
\hline \multirow[t]{2}{*}{ B. K. } & $1-14$ & 13 & $\begin{array}{l}13,300 \\
10,680\end{array}$ & $\begin{array}{l}139 \\
136\end{array}$ & $\begin{array}{l}138 \\
135\end{array}$ & 1,452 & 14 & 104 & 10 & 1 & 115 & 10 & 103 & 113 & -2 \\
\hline & $15-35$ & & & & & & 20 & 0 & 10 & 2 & 12 & 10 & 0 & 10 & -2 \\
\hline \multirow[t]{2}{*}{ B. B. } & $14-29$ & $\begin{array}{l}14 \\
30\end{array}$ & $\begin{array}{l}15,000 \\
12,000\end{array}$ & $\begin{array}{l}134 \\
127\end{array}$ & $\begin{array}{l}129 \\
129\end{array}$ & 1,524 & 16 & 95 & 10 & 1 & 106 & 10 & 103 & 113 & +7 \\
\hline & $30-44$ & & & & & & 15 & $\mathbf{0}$ & 10 . & 1 & 11 & 10 & $\mathbf{0}$ & 10 & -1 \\
\hline
\end{tabular}

suming constant red cell mass) reductions of plasma volumes occurring after paracentesis. These reductions of plasma volume occurred in some cases while edema fluid was rapidly decreasing in dependent areas. In no instance did the hematocrit fall below the control value in this postparacentesis period. Hematocrits often returned to pre-paracentesis levels in four to eight days following paracentesis, but occasionally remained elevated for longer periods.

\section{Sodium Chloride Restriction}

\section{A. Sodium and water balance}

After the periods of sodium ingestion, the added sodium chloride was withdrawn and the basal diet continued. During the initial two to three week period of sodium restriction, accumulation of ascites was abruptly halted and no patient gained appreciable weight except during the first several days after paracentesis as described above. Urine volumes increased by amounts approximating the daily weight gains observed during periods of so- dium ingestion and ranged from $467 \mathrm{ml}$. per day to $793 \mathrm{ml}$. per day, with an average of $680 \mathrm{ml}$. for all patients. This close relation between the rate of weight gain during sodium ingestion and the increases in urine volume resulting from withdrawal of sodium from the diet is indicated in Figure 1 and Table II.

These patients excreted only 0.6 to $3.1 \mathrm{mEq}$. of sodium in the urine daily, regardless of sodium intake. Losses of sodium in the feces in the absence of diarrhea are small and are affected little by marked changes in sodium intake (19). Fecal and sweat losses of sodium were assumed to be $10 \mathrm{mEq}$. daily (19-23). It is possible that sweat losses of sodium were even less than estimated since patients with ascites and subjects on a sodium restricted regimen have reduced sweat sodium concentrations $(20,23,27)$. In contrast to the relatively small amount of the daily sodium intake excreted in the urine, stool and sweat, large losses of body sodium occurred at times of abdominal paracenteses, since the sodium content of the ascitic fluid removed approximated the so- 
dium concentration of the serum. These large losses of sodium entailed by a paracentesis amounted to from $1142 \mathrm{mEq}$. to $2678 \mathrm{mEq}$. Calculations of approximate sodium balances, taking into consideration the losses entailed by paracentesis, indicate that the patients studied are in approximate sodium equilibrium (Table V).

\section{B. Serum sodium}

Serum sodium concentrations in 11 patients with cirrhosis of the liver without ascites and edema ranged from 137 to $146 \mathrm{mEq}$. per L. and averaged $140 \mathrm{mEq}$. per L., values comparable to those found in 18 normal subjects (range 137 to 146 , average $141 \mathrm{mEq}$. per L). Thirty-four patients with ascites in whom this measurement was made shortly after hospitalization and prior to the institution of diuretic therapy, dietary sodium restriction, or paracentesis frequently demonstrated hyponatremia (range 128 to 144 , average 137 mEq. per L.). The lowest average serum sodium value was observed in 17 patients who had had repeated recent paracenteses (range 121 to 143 , average $132 \mathrm{mEq}$. per L.). Although occasionally normal values were obtained, the serum sodium concentrations measured in the patients studied serially were frequently below normal, and the hyponatremia which was often present was more marked in some patients immediately following abdominal paracentesis (Figures 2, 3, 4). The degree of post-paracentesis hyponatremia and the time at which it occurred may be related to the amount of peripheral edema available for mobilization and to the rate of expansion of the ascites. Some patients with massive edema were less likely to display a decrease in serum sodium concentration following paracentesis than those with little or no edema. The relation of hyponatremia to the other physiologic alterations occurring immediately following paracentesis is discussed below.

\section{Prolonged sodium restriction}

Six patients were further studied in the hospital for periods of 60 to 90 days during which the diet rigidly restricted in sodium content was continued. The need for paracentesis was alleviated by continuing the diet providing $10 \mathrm{mEq}$. of sodium daily. Body weights remained the same or increased slowly but ascites and edema did not reaccumulate. Concurrently, there was gradual improvement in their clinical nutritional status, and in most instances the concentration of albumin in the serum increased. In three patients (R. K., Figure 2; B. K., Figure 3; and H. O.) serial hematocrits progressively decreased to values well below those observed early in the studies or immediately following paracentesis. These alterations in hematocrit were paralleled by changes in hemoglobin concentration, so that they could not be attributed to changes in the size of the red blood cells; nor could they be accounted for by blood loss (guaiac tests on all stools were negative). Serial measurements of serum sodium concentrations in these three patients tended to rise with the continued control of ascites formation by dietary sodium restriction. As the hematocrit gradually decreased and the serum albumin and serum sodium values approached the normal range, there occurred a significant increase in the urinary excretion of sodium. This was most marked in patients R. K. (Figure 2) and B. K. (Figure 3) who underwent diureses with losses of weight and excretion of up to 70 $\mathrm{mEq}$. and $85 \mathrm{mEq}$., respectively, daily, although only $10 \mathrm{mEq}$. was being ingested. The time at which significant quantities of sodium appeared in the urine following the institution of the low sodium diet varied from about two to eight weeks.

During a final period of study in patient $B . K$. (Figure 3) $103 \mathrm{mEq}$. of sodium were again given in addition to the basal diet. In contrast to the initial period of study, gain in body weight did not occur and a quantity of sodium approximating that ingested was excreted in the urine. The marked increase in the excretion of sodium in the urine which occurred after the ingestion of sodium was not associated with alteration in the level of urinary potassium excretion.

Two of the patients (J. G., Figure 4 and B. B.) failed to excrete sodium in the urine during 80 and 40 days of observation, respectively. In these instances the serum sodium concentrations were consistently low, and in the case of J. G. the hematocrit increased following paracentesis early in this study and remained above the initially observed values. The hematocrit in $B$. B. generally tended to decrease, but this is not possible to interpret since her course was complicated by intermittent 
episodes of mild to moderate gastro-intestinal bleeding.

No untoward effects were observed in the patients during the prolonged periods of dietary sodium restriction. The incidence of cramps in the legs and fingers was less during the salt restriction periods than when sodium was provided and frequent paracenteses were necessary.

\section{DISCUSSION}

Immediately after paracentesis the following phenomena were observed: a rising hematocrit, rapidly expanding ascites, a decrease in peripheral edema, reduction in urine volume, no change in the minimal urinary sodium excretion, and hyponatremia. These observations can be explained by a rapid transudation of fluid from the circulating plasma into the peritoneal cavity following the reduction of intra-abdominal pressure after paracentesis. Mobilization of edema fluid is attributable to reduction in femoral venous pressure which occurs following paracentesis (7). The post-paracentesis hemoconcentration is accompanied by oliguria and water retention (antidiuresis). Since sodium balance remains unchanged following paracentesis (constant intake and unchanged minimal excretion), the water retention in the immediate post-paracentesis period results in dilution of extracellular fluid and hyponatremia. The retention of water without physiologically equivalent quantities of sodium at this time is corroborated by gains in body weight which were in excess of those expected if sodium was being retained isotonically. That this retention of water may be great enough to produce a symptomatic hyponatremia following paracentesis has been reported (28).

The prevention of the accumulation of ascites and edema by dietary sodium restriction was accompanied in several patients by gradual, but progressive, reductions in hematocrit and increases in serum sodium concentration. When the serum sodium concentration increased to or near to normal, excretion of sodium in the urine recommenced. The source of the sodium for the observed rise in serum sodium concentration, which has also been reported by others (27), in the face of progressive hemodilution, is not clear especially since these patients were on a diet virtually free of sodium.
An intracellular exchange of sodium for potassium may be postulated such as usually is expected following rehydration $(29,30,31)$. However, potassium balance failed to become more positive during this period in the one patient so studied (B. K., Figure 3). Thus, the data, at present limited, do not substantiate this interpretation. Secondly, it is possible that the sodium diuresis may be preceded by a water diuresis. That this may occur is supported by observation of two patients with cirrhosis and ascites who had an initial hyponatremia and who spontaneously underwent a diuresis. These patients displayed increases in serum sodium concentration and losses in body weight prior to the appearance of increases in urinary sodium excretion, suggesting that a diuresis of water preceded that of sodium (32).

The changes observed during prolonged dietary sodium restriction may be related to improvement in liver function and in general nutritional status attributable to the prolonged administration of a nutritious diet (33), the control of ascites formation and the relative degrees of inactivity necessarily accompanying periods of hospitalization.

The results of the present study indicate that abdominal paracentesis leads to a reduction in plasma volume and that repeated paracenteses may result in a chronic state of hemoconcentration and of hyponatremia. Although this interpretation of the data does not explain the genesis of ascites and edema in patients with severe liver disease, it is possible that the initial formation of ascites and edema may lead to a decrease in plasma volume similar in mechanism to that which develops acutely following paracentesis. This would imply that elevated portal pressure and hypoalbuminemia first lead to transudation of fluid from the circulating blood into the peritoneal cavity. The resulting decrease in plasma volume might then provide the stimulus for the appearance of increased antidiuretic activity $(34,35)$, and for the renal conservation of sodium $(36,37)$. The findings of increased antidiuretic activity (13) and decreased quantities of sodium (2-5) in the urine would then be physiologic homeostatic responses. That this may be the case is supported by evidence that patients with liver disease metabolize normally endogenous or physiologic doses of exogenous posterior pituitary hormone $(38-40)$, and by the observations in the present study that progressive 
decreases in hematocrit preceded the onset of a diuresis. The validity of the hypothesis that the effective plasma volume ${ }^{5}$ is reduced in patients with cirrhosis of the liver and ascites awaits the development of methods for making this measurement accurately, particularly in patients with alterations in their plasma proteins, and in their portal vascular beds.

\section{SUMMARY AND CONCLUSIONS}

The effects of sodium chloride administration and restriction and of abdominal paracentesis on electrolyte and water balance were studied in seven patients with cirrhosis of the liver and ascites.

During periods of sodium chloride ingestion, ascites and edema accumulated at a rate approximating that expected if the salt was retained isotonically. When a diet restricted in sodium was provided subsequently the accumulation of fluid was abruptly halted, and daily urine volumes increased by amounts approximating the daily weight gains previously observed during periods of sodium ingestion. With continued dietary sodium restriction improvement in clinical nutritional status, a progressive rise in the serum albumin and sodium concentrations and fall in hematocrit usually occurred. Gradual diuresis with loss of ascites and edema was found to accompany these changes.

Immediately following abdominal paracentesis sodium was not retained isotonically in some patients. Water was retained in excess of salt. This phenomenon is explained as follows: After paracentesis hemoconcentration occurs. The patient responds to this by antidiuresis. Since sodium is already being maximally retained, the resulting water retention contributes to hyponatremia which is most marked following paracentesis.

The studies presented suggest that the effective systemic plasma volume is decreased in patients with cirrhosis of the liver and ascites who have had repeated paracenteses; and that the increased antidiuretic activity and the decreased sodium content of the urine of these patients may be, in part at least, the result of homeostatic responses initiated

5 Systemic plasma volume, exclusive of that contained in the portal vascular bed. by abdominal paracentesis, and also possibly by the initial formation of ascites.

\section{ACKNOWLEDGMENT}

The authors gratefully acknowledge the technical assistance of the Misses Alice Ballou, Virginia Olsson, and Ellen Doyle, Mrs. Frederick S. Bigelow and Mrs. Frederick Hannon, and the dietetic assistance of Mrs. J. Spencer Rochefort and Miss Barbara Wolfe.

\section{REFERENCES}

1. Layne, J. A., and Schemm, F. R., The use of a high fluid intake and a low sodium, acid-ash diet in the management of portal cirrhosis with ascites. Gastroenterology, 1947, 9, 705.

2. Farnsworth, E. B.; and Krakusin, J. S., Electrolyte partition in patients with edema of various origins. J. Lab. \& Clin. Med., 1948, 33, 1534.

3. Eisenmenger, W. J., Ahrens, E. H., Jr., Blondheim, S. H., and Kunkel, H. G., The effect of rigid sodium restriction in patients with cirrhosis of the liver and ascites. J. Lab. \& Clin. Med., 1949, 34, 1029.

4. Faloon, W. W., Eckhardt, R. D., Cooper, A. M., and Davidson, C. S., The effect of human serum albumin, mercurial diuretics, and a low sodium diet on sodium excretion in patients with cirrhosis of the liver. J. Clin. Invest., 1949, 28, 595.

5. Ricketts, W. E., Eichelberger, L., and Kirsner, J. B., Observations on the alterations in electrolytes and fluid balance in patients with cirrhosis of the liver with and without ascites. J. Clin. Invest., 1951, 30, 1157.

6. Blakemore, A. H., Portocaval anastomosis : a report on fourteen cases. Bull. New York Acad. Med., 1946, 22, 254.

7. Davidson, C. S., Gibbons, T. B., and Faloon, W. W., Systemic and portal venous pressure in cirrhosis of the liver. J. Lab. \& Clin. Med., 1950, 35, 181.

8. Peters, J. P., and Eisenman, A. J., The serum proteins in diseases not primarily affecting the cardiovascular system or kidneys. Am. J. M. Sc., 1933, 186,808 .

9. Myers, W. K., and Keefer, C. S., Relation of plasma proteins to ascites and edema in cirrhosis of the liver. Arch. Int. Med., 1935, 55, 349.

10. Butt, H. R., Snell, A. M., and Keys, A., Plasma protein in hepatic disease; a study of the colloid osmotic pressure of blood serum and of ascitic fluid in various diseases of the liver. Arch. Int. Med., 1939, 63, 143.

11. Post, J., and Patek, A. J., Jr., Serum proteins in cirrhosis of the liver. I. Relation to prognosis and to formation of ascites. II. Nitrogen balance studies on five patients. Arch. Int. Med., 1942, 69, 67, 83.

12. Post, J., and Patek, A. J., Jr., Serum proteins in relation to liver disorders. Bull. New York Acad. Med., 1943, 19, 815. 
13. Ralli, E. P., Robson, J. S., Clarke, D., and Hoagland, C. L., Factors influencing ascites in patients with cirrhosis of the liver. J. Clin. Invest., 1945, 24, 316.

14. Mankin, H., and Lowell, A., Osmotic factors influencing the formation of ascites in patients with cirrhosis of the liver. J. Clin. Invest., 1948, 27, 145.

15. Goodyer, A. V. N., Relman, A. S., Lawrason, F. D., and Epstein, F. H., Salt retention in cirrhosis of the liver. J. Clin. Invest., 1950, 29, 973.

16. Consolazio, W. V., and Dill, D. B., The determination of sodium. J. Biol. Chem., 1941, 137, 587.

17. Hald, P. M., The flame photometer for the measurement of sodium and potassium in biological materials. J. Biol. Chem., 1947, 167, 499.

18. Wallace, W. M., Holliday, M., Cushman, M., and Elkinton, J. R., The application of the internal standard flame photometer to the analysis of biologic material. J. Lab. \& Clin. Med., 1951, 37, 621.

19. Leaf, A., and Couter, W. T., Evidence that renal sodium excretion by normal human subjects is regulated by adrenal cortical activity. J. Clin. Invest., 1949, 28, 1067.

20. McCance, R. A., Experimental sodium chloride deficiency in man. Proc. Roy. Soc., London, Series B., 1936, 119, 245.

21. Freyberg, R. H., and Grant, R. L., Loss of minerals through the skin of normal humans when sweating is avoided. J. Clin. Invest., 1937, 16, 729.

22. Keutmann, E. H., Bassett, S. H., and Warren, S. L., Electrolyte balances during artificial fever with special reference to loss through the skin. J. Clin. Invest., 1939, 18, 239.

23. Arn, K.' D., and Reimer, A., Minimal sodium losses through the skin. J. Clin. Invest., 1950, 29, 1342.

24. Mateer, J. G., Baltz, J. I., Marion, D. F., and MacMillan, J. M., Liver function tests. A general evaluation of liver function tests, and an appraisal of the comparative sensitivity and reliability of the newer tests, with particular emphasis on the cephalin-cholesterol flocculation test, the intravenous hippuric acid test and an improved bromsulphalein test with a new normal standard. J.A.M.A., 1943, 121, 723.

25. Gitlin, D., Davidson, C. S., and Wetterlow, L. H., The quantitative estimation of serum albumin in human body fluids by direct titration with specific horse antiserum. J. Immunol., 1949, 63, 415.
26. Wintrobe, M. M., Clinical Hematology, ed. 2, Philadelphia, Lea and Febiger, 1946, p. 242.

27. Eisenmenger, W. J., Blondheim, S. H., Bongiovanni, A. M., and Kunkel, H. G., Electrolyte studies on patients with cirrhosis of the liver. J. Clin. Invest., 1950, 29, 1491.

28. Nelson, W. P., III, Rosenbaum, J. D., and Strauss, M. B., Hyponatremia in hepatic cirrhosis following paracentesis. J. Clin. Invest., 1951, 30, 738.

29. Elkinton, J. R., and Winkler, A. W., Transfers of intracellular potassium in experimental dehydration. J. Clin. Invest., 1944, 23, 93.

30. Elkinton, J. R., Winkler, A. W., and Danowski, T. S., Transfers of cell sodium and potassium in experimental and clinical conditions. J. Clin. Invest, 1948, 27, 74.

31. Danowski, T. S., Newer concepts of the role of potassium in disease. Am. J. Med., 1949, 7, 525.

32. Gabuzda, G. J., Unpublished observations.

33. Patek, A. J., Jr., and Post, J., Treatment of cirrhosis of the liver by a nutritious diet and supplements rich in vitamin B complex. J. Clin. Invest., 1941, $20,481$.

34. Leaf, A., and Mamby, A. R., An antidiuretic mechanism not regulated by extracellular fluid tonicity. J. Clin. Invest., 1952, 31, 60.

35. Welt, L. G., and Orloff, J., The effects of an increase in plasma volume on the metabolism and excretion of water and electrolytes by normal subjects. J. Clin. Invest., 1951, 30, 751.

36. Peters, J. P., The role of sodium in the production of edema. New England J. Med., 1948, 239, 353.

37. Peters, J. P., Sodium, water, and edema. J. Mt. Sinai Hospital, 1950, 17, 159.

38. White, A. G., Rubin, G., and Leiter, L., Studies in edema. III. The effect of Pitressin on the renal excretion of water and electrolytes in patients with and without liver disease. J. Clin. Invest., 1951, 30, 1287.

39. Nelson, W. P., III, and Welt, L. G., The effects of Pitressin on the metabolism and excretion of water and electrolytes in normal subjects and patients with cirrhosis and ascites. J. Clin. Invest., 1952, $31,392$.

40. Bernstein, S. H., Weston, R. E., Ross, G., Grossman, J., Hanenson, I. B., and Leiter, L., Studies on intravenous water diuresis and nicotine and Pitressin antidiuresis in normal subjects and patients with liver disease. J. Clin. Invest., 1953, 32, 422. 